\title{
O PRAWDZIE W LITERATURZE UWAG KILKA
}

\begin{abstract}
Streszczenie. Artykuł podejmuje zagadnienie prawdy w literaturze. Punktem wyjścia dla analiz jest koncepcja Romana Ingardena. Odmawia on dziełu literackiemu jako dziełu sztuki prawdziwości w sensie logicznym. Według Ingardena literackie dzieło sztuki jako przedmiot czysto intencjonalny niczego nie orzeka o świecie transcendentnym. Prawdę w dziele literackim można jednakże ujmować jako jej objawianie.
\end{abstract}

Słowa kluczowe: prawda; dzieło literackie; Roman Ingarden

1. Wstęp. 2. Kontekst metodologiczny stanowiska Ingardena. 3. Główne tezy Ingardenowskiej koncepcji dzieła literackiego. 4. Stanowisko Ingardena dotyczące prawdy w dziele literackim. 5. Zakończenie - w kierunku dalszych badań.

\section{WSTĘP}

Problem prawdy w dziele literackim jest ciągle żywym problemem, absorbującym wielu badaczy z różnych dziedzin nauki, w szczególności zaś filozofii i teorii literatury. Dostrzegają oni doniosłość tego zagadnienia, którą wyznacza sama kategoria prawdy, przynależna do triady najwyższych wartości i transcendentaliów bytowych. Niewypowiedzianym przeświadczeniem pisarzy i badaczy jest to, że pozbawienie literatury pięknej prawdziwości usuwa spod niej mocny fundament jej wartości. Wychodząc od stanowiska Romana Ingardena, chciałabym zasygnalizować inny kierunek możliwych poszukiwań rozwiązania zagadnienia prawdy w literaturze, zdając sobie sprawę, że stanowisko Ingardena, przyjęte za wyjściowe dla problemu, nie wyczerpuje komplementarnych jego ujęć zarówno filozoficznych, jak i - przede wszystkim - teoretycznoliterackich. 


\section{KONTEKST METODOLOGICZNY STANOWISKA INGARDENA}

W swym podstawowym dziele z estetyki, a właściwie - jak głosi podtytuł owego dzieła - zpogranicza ontologii, teorii języka i flozofii literatury, czyli w wydanej pierwotnie po niemiecku w 1931 roku, a przetłumaczonej na polski i wydanej w 1960 roku książce $O$ dziele literackim ${ }^{1}$, Roman Ingarden zagadnienie prawdy w literaturze podejmuje w końcowej części jej drugiej i zasadniczej części, poświęconej budowie dzieła literackiego ${ }^{2}$. Część tę poprzedzają wstępne uwagi, zmierzające do wyodrębnienia właściwego przedmiotu badań, jakim jest dzieło literackie, sprecyzowania aspektu, w jakim dzieło literackie ma być badane, oraz zasygnalizowania rozwiązań, w opozycji do których pozostaje Ingardenowska koncepcja dzieła literackiego. Część trzecia to uzupełnienia i konsekwencje owej koncepcji, wyłożonej w części drugiej, obejmująca wypadki graniczne, problematykę „życia” dzieła literackiego, jego miejsca w bycie oraz - kończące całość - zagadnienie jego jedności jako polifonicznej harmonii estetycznych jakości wartościowych.

Poza książką O dziele literackim zagadnieniu prawdy w literaturze Ingarden poświęcił jeszcze dwa teksty: pochodzący z 1946 roku artykuł O różnych rozumieniach „Prawdziwości” w dziele sztuki3 oraz

1 Pierwsze wydanie Das literarische Kunstwerk. Eine Untersuchung aus dem Grenzgebiet der Ontologie, Logik und Literaturwissenchaft ukazało się w 1931 roku w Halle w Max Niemeyer Verlag. Wydanie polskie pt. O dziele literackim. Badania z pogranicza ontologii, teorii języka i filozofii literatury, w tłumaczeniu M. Turowicz, ukazało się w Państwowym Wydawnictwie Naukowym w Warszawie w 1960 roku, oraz wydanie drugie - z którego korzystam - w 1988 roku.

2 Przedmiotem analiz Ingardena w O dziele literackim jest idea 'dzieło literackie', pod którą podpadają różnego rodzaju dzieła literackie, w tym dzieło naukowe. Niemniej w centrum Ingardenowskiej uwagi było „literackie dzieło sztuki”, tak więc gdy w tym artykule jest mowa o 'dziele literackim', mam na uwadze przede wszystkim 'literackie dzieło sztuki'.

3 Pierwotnie ten artykuł ukazał się w Zagadnieniach Literackich 10(1946)1, 12-19 oraz 10(1946)2, 36-43. W wersji poprawionej i poszerzonej znalazł się on w t. 1 Studiów z estetyki, Warszawa 1966, 395-412. 
pochodzący z 1937 roku artykuł O tak zwanej „Prawdzie” w literatu$r z e^{4}$. Jak to sam oświadczył, oba teksty powstały, aby wyjaśnić jego własne stanowisko, dotyczące "prawdziwości” dzieła literackiego, przedstawione w Das literarische Kunstwerk, czyli w pierwotnej niemieckiej jeszcze wersji przywołanego tu dzieła 5 .

Analizując Ingardenowską koncepcję dzieła literackiego, trzeba nieustannie pamiętać, że jej rdzeń stanowi ontologia, która poddaje apriorycznej analizie zawartość określonych idei - w tym przypadku: idei 'dzieło literackie'. Swe tezy uzasadnia w czystym uchwyceniu jakości idealnych i koniecznych związków, jakie między nimi zachodzą, które przedłuża się w analizę czystych możliwości, jakie z tego, co stwierdzono w zawartości idei, wynikają dla indywidualnego bytu ${ }^{6}$. Badania ontologiczne nie wyczerpują wszystkich aspektów badawczych, dotyczących jakiegokolwiek przedmiotu, a więc także i dzieła literackiego. Ujawnia się to w dopełnieniu przez Ingardena książki $O$ dziele literackim równie obszernym studium pt. O poznawaniu dzieta literackiego ${ }^{7}$, a także pomniejszymi pracami z estetyki i aksjologii ${ }^{8}$, które niekiedy wprost, a niekiedy jedynie pośrednio dotyczą dzieła literackiego. Ingarden w swych badaniach kierował się zasadą, by nie tworzyć jakiegoś systemu, lecz każde zagadnienie rozważać autonomicznie, poddając się intuicyjnemu uchwyceniu przedmiotu, bez odwoływania się do wcześniejszych rozwiązań9. A mimo to jego teksty (nie tylko te, dotyczące dzieła literackiego, lecz jego cała twórczość filozoficzna) tworzą spójną, wzajemnie uzu-

4 Pierwotnie został on wydrukowany w Przeglądzie Współczesnym 61(1937)182, 80-94, oraz 61(1937)183, 72-91, którego wersja poszerzona i poprawiona również została zamieszczona w t. 1 Studiów z estetyki, dz. cyt., 415-464. W niniejszym artykule będę powoływała się na wersje obu tekstów ze Studiów z estetyki.

5 R. Ingarden, Przedmowa, w: Tenże, Studia z estetyki, t. 1, Warszawa 1966, VI.

6 Por. Tenże, Spór o istnienie świata, t. 1, Ontologia egzystencjalna, Warszawa 19873, 45.

7 Tenże, O poznawaniu dzieła literackiego, tłum. z niem. D. Gierulanka, Warszawa 1976.

8 Zostały one opublikowane przede wszystkim w Szkicach z filozofii literatury (Łódź 1947; Kraków 2000) oraz w trzech tomach Studiów z estetyki, Warszawa 1966-1970.

9 R. Ingarden, Przedmowa, w: Tenże, Studia z estetyki, t. 3, Warszawa 1970, 5-6. 
pełniającą się całość, co przekonywująco przedstawiała Danuta Gierulanka ${ }^{10}$, wskazując m.in. na centralny problem Ingardenowskich badań, jakim był spór o istnienie świata, czyli próba rozwiązania sporu między idealizmem a realizmem. Ów spór poniekąd wyznacza ramy obowiązywalności twierdzeń Ingardena, ale też ich rozumienia. W spór ten wpisuje się też problematyka dzieła literackiego, a wraz $z$ nią problematyka prawdy w literaturze przez to, że dzieło literackie jest przykładem przedmiotu czysto intencjonalnego, wytworzonego przez świadomość, za jaki to przedmiot idealiści uważali cały świat.

\section{GŁÓWNE TEZY INGARDENOWSKIEJ KONCEPCJI DZIEŁA LITERACKIEGO}

Jak wiadomo, według Ingardena dzieło literackie jest tworem wielowarstwowym i wielofazowym. Cztery wyróżnione przez niego warstwy, to warstwa językowych tworów brzmieniowych, warstwa tworów znaczeniowych, warstwa uschematyzowanych wyglądów i warstwa (szeroko rozumianych ${ }^{11}$ ) przedmiotów przedstawionych, tworzących świat przedstawiony $\mathrm{w}$ dziele. Wszystkie one, będąc względem siebie heterogeniczne, a jednocześnie ściśle ze sobą powiązane poprzez właściwe im funkcje, składają się na dzieło literackie. Tak przedstawiająca się struktura dzieła literackiego jest dopełniona przez uporządkowanie jego części według zasady następstwa, którego to uporządkowania nie należy pojmować w sensie czysto czasowym. O ile warstwowa budowa dzieła literackiego ujawnia jego strukturę poprzeczną, o tyle porządek następstwa ujawnia jego strukturę podłużną. Dzięki niej możliwa jest konkretyzacja dzieła literackiego w konkretnym przedziale czasowym.

10 D. Gierulanka, Filozofia Romana Ingardena. Próba wniknięcia w strukturę całości dzieła, w: Fenomenologia Romana Ingardena, (Wydanie specjalne Studiów Filozoficznych), red. J. Kuczyński i in., Warszawa 1972, 70-90.

11 Jak wyjaśnia Ingarden, przez przedmiot przedstawiony należy rozumieć wszystko, „co jest nazwowo zaprojektowane, bez względu na to, jaka byłaby jego kategoria przedmiotowa i materialna istota" (R. Ingarden, O dziele literackim, dz. cyt., 284). 
Dzieło literackie jako wytwór twórczej świadomości jego autora nie jest przedmiotem realnym, lecz czysto intencjonalnym. Za taki Ingarden uważał każdy przedmiot, który „zostaje wytworzony bezpośrednio lub pośrednio przez akt świadomościowy lub przez mnogość takich aktów wyłącznie dzięki immanentnej im intencjonalności, tak iż w aktach tych ma źródło swego bytu i zupełnego swego uposażenia"12. W przypadku np. dzieła literackiego, w aktach świadomościowych, spełnianych przez podmiot, ma ono nie tylko swe źródło bytu i uposażenia, lecz i utrwalenia w bytowo silniejszej podstawie, jaką jest język, który sam w sobie też jest przedmiotem czysto intencjonalnym, utrwalonym w piśmie lub mowie. Dzięki temu „utrwaleniu” dzieło literackie, choć zależne od aktów intencyjnych twórcy, cieszy się względną niezależnością. Istnieje dłużej niż same akty i jest intersubiektywnie dostępne różnym podmiotom świadomości ${ }^{13}$.

Dla rozważenia zagadnienia prawdy w dziele literackim należy zwrócić uwagę na jeszcze jeden element Ingardenowskiej koncepcji dzieła literackiego. Poza dziełem naukowym, w którym zasadniczo występują sądy w sensie logicznym, w literackich dziełach sztuki (zwłaszcza w nich) sądy takie w zasadzie nie występują, a zdania orzekające są tylko quasi-sądami. Świat przedstawiony nie jest bowiem rzeczywistym światem, lecz światem przedstawionym właśnie w quasi-sądach oraz w innego rodzaju językowych tworach znaczeniowych, które można nazwać quasi-pytaniami, quasi-rozkazami, quasi-obietnicami itp. W przeciwieństwie do sądów w sensie logicznym, które poprzez wytwarzany przez siebie intencjonalny

12 Tenże, O dziele literackim, dz. cyt., 179. Szerzej na ten temat: tamże, 179-247 oraz Tenże, Spór o istnienie świata, t. 2: Ontologia formalna, cz. 1: Forma i istota, Warszawa 19873, 162-211, 472-476.

13 Por. Tenże, O poznawaniu dzieła literackiego, dz. cyt., 21. Na marginesie: owa intersubiektywność dzieła literackiego, mająca swą podstawę w języku jako jego bytowej podstawie, pozwala obcować z dziełem literackim na różne sposoby, w tym badać je w różnych aspektach. 
stan rzeczy odnoszą się do przedmiotów nie czysto intencjonalnych (realnych czy idealnych), quasi-sądy wyczerpują się w ustanawianiu świata przedstawionego i jego składowych, czysto intencjonalnej quasi-rzeczywistości ${ }^{14}$. I dlatego - do czego jeszcze powrócę - jedynie sądy w sensie logicznym: „nie tylko roszczą sobie prawo do prawdziwości, lecz są prawdziwe lub fałszywe"15, natomiast quasi-sądy są owego roszczenia pozbawione, gdyż niczego nie stwierdzają na serio.

$\mathrm{Na}$ początku niniejszych rozważań stwierdziłam, że w książce O dziele literackim zagadnienie prawdy w literaturze Ingarden podejmuje pod koniec jej drugiej i zasadniczej części, gdy zasygnalizowane powyżej istotne elementy jego koncepcji dzieła literackiego zostały już wyłożone. Dopiero - jeśli można tak powiedzieć - pełne ukształtowanie się dzieła w czterech podstawowych warstwach pozwala objawić się w nim, a w szczególności w świecie w nim przedstawionym, jakościom metafizycznym ${ }^{16}$. Istotne dla zagadnienia prawdy w literaturze $^{17}$ jest i to, że jakości metafizyczne, które niejako unoszą się nad określonymi sytuacjami życiowymi i zdarzeniami, jakie zachodzą między ludźmi, a zatem przynależą do sfery przedmiotowej i same

14 Tenże, O dziele literackim, dz. cyt., 229-274.

15 Tamże, 229.

16 Za takie Ingarden uważa m.in. wzniosłość lub podłość, tragiczność lub straszliwość, to, co wstrząsające, niepojęte lub tajemnicze, demoniczność, świętość lub grzeszność, piekielność (np. czyjejś zemsty), ekstatyczność (najwyższego zachwytu) lub ciszę (ostatecznego ukojenia), groteskowość lub patetyczność, uroczystość jakiegoś obrzędu, wdzięk lub lekkość, powagę lub ciężkość. Por. Tenże, O dziele literackim, dz. cyt., 369.

17 Zagadnienie jakości metafizycznych było wielokrotnie podejmowane przez licznych badaczy. Poświęciłam mu dwa artykuły: Jakości metafizyczne w dziele literackim, Kwartalnik Filozoficzny 36(2008)2, 123-131 oraz Jakości metafizyczne w dziele sztuki literackiej i ich poznawanie, Studia Philosophiae Christianae 50(2014)2, 125-144. Szczególnie ważne dla zrozumienia Ingardenowskiej koncepcji jakości metafizycznych są następujące prace: W. Stróżewski, Jakości metafizyczne, w: Słownik pojęć filozoficznych Romana Ingardena, red. A.J. Nowak, L. Sosnowski, Kraków 2001, 130-131 (tekst ten został także opublikowany w zbiorze: Od teorii literatury do ontologii świata, red. J. Perzanowski, A. Pietruszczak, Toruń 2003, 81-91) oraz A. Tyszczyk, Estetyczne i metafizyczne aspekty aksjologii literackiej Romana Ingardena, Lublin 1993, 67-90. 
w sobie nie są subiektywnymi odczuciami, w dziele literackim: „nie są po prostu momentami świata przedstawionego, określonymi przez sens zdań i przedstawionymi przez intencjonalne korelaty zdań, tak jak same przedmioty przedstawione" ${ }^{18}$. Jakości metafizycznych nie da się bowiem przedstawić za pomocą środków językowych, a szerzejza pomocą jakichkolwiek środków artystycznych. W dziele sztuki, w tym w dziele literackim, mogą się one jedynie objawić, jeśli na to pozwoli sytuacja przedmiotowa, zbudowana $\mathrm{w}$ doniosły artystycznie sposób przez autora dzieła ${ }^{19}$. Ingarden pisze: „objawiające się jakości metafizyczne dochodzą do samoodsłonięcia się na podłożu przedstawionych sytuacji i jako odsłonięte (w konkretyzacji) w ten sposób się naocznie ukazują jako świat przedmiotów"20.

Przez sens zdań i ich intencjonalnych korelatów nie da się też przedstawić „idei” dzieła literackiego, pod którym to terminem Ingarden pojmuje doprowadzenie „do naocznego ujawnienia związku $z$ istoty płynącego między określoną przedstawioną sytuacją życiową, jako fazą kulminacyjną poprzedzającego ją rozwoju wypadków, a jakością metafizyczną, która na tle tej sytuacji się ukazuje i z jej zawartości czerpie swoiste zabarwienie”. I dodaje: „Na odsłonięciu takiego $\mathrm{z}$ istoty płynącego związku, którego niepodobna ściśle nazwać ani czysto pojęciowo określić, polega czyn twórczy poety. Ów zaś związek, raz odkryty i ujrzany, pozwala zarazem »zrozumieć" wewnętrzne powiązania poszczególnych faz dzieła i uchwycić całe dzieło sztuki jako twór z jednej bryły"21.

18 R. Ingarden, O dziele literackim, dz. cyt., 374.

19 Znaczy to, że objawienie się jakości metafizycznych w dziele literackim (w dziele sztuki), mimo iż niezależne od intencji twórczej, jest szczytowym owocem artystycznej wartości dzieła.

20 R. Ingarden, O dziele literackim, dz. cyt., 377.

21 Tamże, 381-383. Takie rozumienie „idei” dzieła trzeba odróżnić od odrzuconego przez Ingardena takiego jej rozumienia, które pozwala na wyrażenie jej przez prawdziwe zdania w sensie logicznym. 
Jakości metafizyczne oraz tzw. „idea” dzieła literackiego, tak jak ją pojmował Ingarden, pokazują, że nie wszystkie „składowe” dzieła literackiego wyznaczone są przez znaczenia wyrażeń językowych, tworzących dane dzieło. Jest to wskazówką, że być może i na zagadnienie prawdy w dziele literackim należy spojrzeć szerzej.

\section{STANOWISKO INGARDENA DOTYCZĄCE PRAWDY W DZIELE LITERACKIM}

Ingardenowskie stanowisko odnośnie do zagadnienia prawdy w dziele literackim wydaje się w pełni jasne: kategoria prawdy w sensie ścisłym, logicznym czy epistemicznym nie przysługuje dziełu sztuki literackiej. Ingarden pojmuje prawdę klasycznie i definiuje ją w następujący sposób: „sąd jest »prawdziwy«, jeżeli stan rzeczy wyznaczony przez jego treść zachodzi niezależnie od istnienia sądu w obrębie tej dziedziny bytu, w której dany sąd go umieszcza" 22 . Z samej tej definicji wynika, że nie może być mowy o sądach prawdziwych w literackim dziele sztuki, gdyż nie odnoszą się one do stanów rzeczy, niezależnych od tych sądów. Nie dostosowują się one do niezależnego od nich przedmiotu, w które trafia promień intencji aktu poznawczego, tak aby móc ów przedmiot jak najpełniej zaprezentować, lecz jedynie, jako jego silniejsza bytowa podstawa, przedstawiają świat wytworzony przez akty twórcze, jednocześnie o nim informując. Sądy sensu stricto są wytworami aktów poznawczych, natomiast quasi-sądy - aktów twórczych czy wytwórczych. Tak to przedstawia Ingarden: „Sądzenie wyrasta z podłoża odbiorczego poznawania przedmiotów zastanych przez podmiot, narzucających się jemu. Natomiast quasi-sądzenie rodzi się na tle aktów (umyślnie lub mimo woli) wytwórczych, aktów fantazji poetyckiej, których ostatecznym zamierzeniem jest nie proste, możliwie wierne dostosowanie się do tego, co jest przed ich dokonaniem się, lecz przeciwnie, wyjście poza świat zastany, cza-

22 R. Ingarden, O różnych rozumieniach „Prawdziwości” w dziele sztuki, dz. cyt., 396. 
sem nawet wyswobodzenie się od niego właśnie przez wytworzenie - na pozór - nowego świata"23. Świat przedstawiony w dziele literackim nie jest rzeczywistością niezależną od przedstawiających go wyrażeń językowych, w tym - zdań oznajmujących, lecz jedynie quasi-rzeczywistością „osadzoną” w quasi-sądach. Ingarden w swych badaniach dzieła literackiego odnosił się do dzieła gotowego, które ukończone przez twórcę pozostaje niezmienne w warstwie brzmień słownych i znaczeń ${ }^{24}$. Przy takim ujęciu quasi-sądy i inne wyrażenia językowe użyczają przedmiotom przedstawionym pewnego przejawu rzeczywistości i wyznaczają ich przedmiotową treść, a jednocześnie o nich informują tak, że wyznaczanie owej przedmiotowej treści i informowanie o niej stanowią niezapośredniczoną jedność, co jest specyfiką wszelkich aktów intencyjnych i przedmiotów czysto intencjonalnych ${ }^{25}$. W ten sposób można by powiedzieć, że wszelkie sądy literackiego dzieła sztuki są prawdziwe, bo stwierdzają to, co same głoszą, co jednakże oddala nas od problemu, podjętego przez Ingardena, a przynajmniej go nieco modyfikuje. Jest bowiem oczywiste, że dzieło literackie jako wartościowe dzieło sztuki jest pewną organiczną całością, zamkniętą w sobie również w tym sensie, że jako takie ze swej istoty nie odnosi się do niczego wobec siebie transcendentnego, chyba że drugorzędnie, w sposób mniej lub bardziej zamierzony, gdy pełni jeszcze inne zadania, takie jak np. literatura non-fiction, literatura faktu, a wówczas owa zamknięta całość, stanowiąc literackie dzieło artystyczne, chce być wierna rzeczywistości pozaliterackiej. Jednakże wierność faktom jedynie odróżnia ten gatunek literacki (jako jego differentia specifica) i wyodrębnia go spośród innych gatunków literackich, lecz nie decyduje o artystycznej i estetycznej kwalifikacji dzieła. Innymi słowy, nawet gdyby się okazało, że okre-

23 Tenże, O tak zwanej „Prawdzie” w literaturze, dz. cyt., 420-421.

24 Por. J. Krokos, O poznawaniu przedmiotów czysto intencjonalnych, Kwartalnik Filozoficzny 34(2008)2, 15-23.

25 Por. Tenże, Trójwymiar intencjonalności, Studia Philosophiae Christianae 52(2016)3, 51-67. 
ślone dzieło literackie, zaliczane do literatury faktu, opisywane fakty fałszuje, to pozostaje ono literackim dziełem artystycznym, jeśli jest nośnikiem właściwych takiemu dziełu wartości artystycznych i estetycznych. A zatem - co trzeba zaakcentować - Ingardenowska teoria quasi-sądów, której konsekwencją jest zakwestionowanie ich prawdziwości logicznej i epistemicznej, ma na uwadze dzieło literackie li tylko jako dzieło sztuki, czyli jako taki wytwór świadomości twórczej, który charakteryzuje się określonymi jakościami (wartościami) artystycznymi, umożliwiającymi pojawienie się w przedmiocie estetycznym (w konkretyzacji dzieła) jakości (wartości) estetycznie doniosłych ${ }^{26}$.

Ingarden uważa za źródłowe (pierwotne), ścisłe, jednoznaczne i merytorycznie zasadne jedynie logiczne i epistemiczne pojmowanie prawdy. Dostrzega jednakże możliwość użycia tego terminu w odniesieniu do dzieła literackiego. Szerzej sprawę omawia we wspomnianym już artykule $O$ różnych rozumieniach „Prawdziwości” w dziele sztuki. Wymienia tam następujące, przenośne czy metaforyczne, użycia terminu „prawdziwość” lub „prawda”: (1) „prawdziwość, odnosząca się do przedmiotów przedstawionych w literackim dziele sztuki, pojmowana jako „wierność" reprezentowania przedmiotu pozaartystycznego przez przedmiot przedstawiony czy proste podobieństwo do niego, jako przedmiotowa konsekwencja, jako nabranie przez przedmiot przedstawiony charakteru autonomii bytowej oraz jako doskonałość jego ucieleśnienia; (2) „prawdziwość” jako odpowiedniość środków przedstawienia do przedmiotu przedstawionego; (3) „prawdziwość” jako zwartość zestroju momentów jakościowych dzieła; (4) „prawdziwość”, przysługująca literackiemu dziełu sztuki z uwagi na jego stosunek do autora - szczerość i prawdomówność wypowiadania się autora o przedmiocie, dojrzałość dzieła jako udatność realizacji

26 Zainteresowanych problematyką jakości (wartości) artystycznych i estetycznych odsyłam do tekstów samego Ingardena oraz licznych opracowań na ten temat, które trudno tu przywoływać. 
zamierzenia autora, szczerość dzieła w wyrażaniu osobowości autora; (5) „prawdziwość” dzieła jako jego sprawność oddziaływania na perceptora; (6) „prawdziwość” w tym sensie, że dane dzieło jest naprawdę literackim dziełem sztuki; (7) „prawdziwość” idei dzieła.

Przywołane tu znaczenia „prawdziwości” dotyczą różnych aspektów literackiego dzieła sztuki. Jedynie przy pierwszym znaczeniu „prawdziwości” mamy na uwadze pewną modyfikację logiczno-epistemicznej koncepcji prawdy, gdzie miejsce sądu zajmuje przedmiot przedstawiony jako swoiste quasi-ikoniczne przedstawienie przedmiotu pozaartystycznego. Znaczenie drugie i trzecie odnosi się do warsztatu pisarskiego, do środków artystycznych, zastosowanych przy tworzeniu dzieła, które leżą w kręgu zainteresowań literaturoznawczych. $Z$ kolei znaczenie czwarte dotyczy aktów twórczych, zaś piąte - percepcji dzieła, czyli zagadnień właściwych badaniom psychologii i socjologii twórczości i kultury. Poprzez znaczenie szóste wracamy do filozofii i teorii literatury, które uchwytują istotę literackiego dzieła sztuki, oraz przenosimy się do literaturoznawstwa i krytyki literackiej, które w świetle ustaleń filozoficzno- i teorioliterackich kwalifikują określony wytwór jako dzieło sztuki27. I znaczenie siódme, w którym metaforyczność „prawdziwości” zlewa się z wieloznacznością „idei dzieła”, którą jeśliby uznać za syntetyczne ujęcie jego treści, prowadziłoby to do zmodyfikowanej logiczno-epistemicznej prawdy (według Ingardena nieobecnej w literackim dziele sztuki), gdyby zaś „ideę dzieła” rozumieć po Ingardenowsku, jak to zostało wyżej przytoczone, „prawdziwość” odnosiłaby się do warsztatu pisarza.

27 Problem z tym znaczeniem „prawdziwości” związany jest z językiem polskim, który nie posiada odpowiednika np. niemieckiego echt z całym jego wachlarzem znaczeń. W języku polskim dzieło 'prawdziwe' to nie to samo co 'autentyczne', by ograniczyć się do tych dwóch znaczeń niemieckiego przymiotnika. Gdy mówi się o czymś, że jest 'prawdziwe' w przywołanym tu znaczeniu, to chodzi o to, że nie udaje czegoś, czym nie jest, jak tombak jedynie udaje złoto, lecz prawdziwym złotem nie jest. 


\section{ZAKOŃCZENIE - W KIERUNKU DALSZYCH BADAŃ}

Stanowisko Ingardena odnośnie do "prawdy” w literackim dziele sztuki (a „prawdę" w dziele) trzeba wyraźnie odróżnić od „prawdy” czy „prawdziwości” dzieła, i jest to w pełni zasadne, jeśli ma się na uwadze dzieło literackie jako dzieło sztuki, a prawdę jako osobliwą (intencjonalną) zgodność rezultatu poznania z poznawanym przedmiotem. Choć spełnia ono liczne pozaestetyczne funkcje, w tym często i funkcje poznawcze, informując - niekiedy nawet bardzo rzetelnie - o rzeczywistości pozaestetycznej, o osobowości i życiowych doświadczeniach autora, choć wpływa - często bardzo skutecznie ${ }^{28}$ - na życie człowieka i społeczności, to jednak wszystko to wykracza poza istotę dzieła literackiego jako dzieła sztuki. „Sztuka w ogóle a sztuka literacka w szczególności ma inne zadania w życiu człowieka, niż pouczanie go przy pomocy sądów, jakim jest otaczający go świat rzeczywisty, i innymi w spełnianiu swych zadań środkami rozporządza niż sądy sensu stricto. Funkcją jej naczelną jest pokazywać pewne możliwe i konieczne związki między jakościowym uposażeniem przedmiotów (w szczególności ludzi) a wartościami, i poprzez działanie na życie wzruszeniowe człowieka umożliwić mu obcowanie bezpośrednie z wartościami. Przy tym wartości te moga być bardzo różnorodne, a jakie w poszczególnych wypadkach, to zależy od zawartości dzieła sztuki. Ale dostęp do ich doświadczenia szczególnego typu otwiera m.in. postawa estetyczna, w którą dzieło sztuki wprawia perceptora przez działanie na niego. $W$ tym działaniu quasi-sądy stanowią jeden ze środków przyczyniających się do rozwoju przeżycia estetycznego. Czy się w tym wszystkim wyczerpuje

28 Przykładem jest instrumentalne wykorzystywanie sztuki, a szczególnie literatury, w celach propagandowych, co było i jest najwyraźniej widoczne w politycznych systemach totalitarnych. 
rola sztuki w życiu człowieka, to pytanie nowe, którego tu nie mam zamiaru rozstrzygać" 29 .

Tyle Ingarden. Czy jednak w ten sposób zagadnienie „prawdy” w literackim dziele sztuki zostaje definitywnie rozstrzygnięte? Czy uznając osobliwość sztuki, w tym sztuki literackiej, która istotnie różni ją od innych dziedzin kultury, w tym - przede wszystkim - od nauki, należy co do „prawdy” pojmowanej klasycznie przeprowadzić między sztuką a nauką wyrazistą linię demarkacyjną? Inspirujące do dalszych badań tego zagadnienia jest jedno zdanie z przywołanego zakończenia artykułu O tak zwanej „Prawdzie" w literaturze oraz niezgoda pisarzy (a także teoretyków literatury i literaturoznawców) na pozbawienie dzieła literackiego klasycznie rozumianej prawdy, która to niezgoda nie wynika, albo nie zawsze wynika, $\mathrm{z}$ niezrozumienia istoty stanowiska odnośnie do prawdy w literaturze, które wyraził Ingarden ${ }^{30}$.

Zdanie Ingardena, które mam tu na myśli, brzmi: „Funkcją jej [sztuki - W.T.] naczelną jest pokazywać pewne możliwe i konieczne związki między jakościowym uposażeniem przedmiotów (w szczególności ludzi) a wartościami, i poprzez działanie na życie wzruszeniowe człowieka umożliwić mu obcowanie bezpośrednie z wartościami”. Otóż, jak się wydaje, istota literackiej prawdy, prawdy w literackim dziele sztuki, nie polega na wydawaniu pojedynczych sądów (czy sądów powiązanych ze sobą w system) o przedmiotach transcendentnych, o transcendentnym świecie, lecz polega właśnie na pokazywaniu czegoś, co - nie znajdując lepszego określenia można za Ingardenem nazwać możliwymi i koniecznymi związkami

29 R. Ingarden, O tak zwanej „Prawdzie” w literaturze, dz. cyt., 463-464.

30 O szerokości i złożoności dyskusji na ten temat świadczyć mogą następujące publikacje: D. Ulicka, Granice literatury i pogranicza literaturoznawstwa. Fenomenologia Romana Ingardena w świetle filozofii lingwistycznej, Warszawa 1999, 153-196; Prawda w literaturze, red. A. Tyszczyk, J. Borowski, I. Piekarski, Lublin 2009; J. Ziomek, Prawda jako problem poetyki, w: Tenże, Prace ostatnie. Literatura i nauka o literaturze, Warszawa 1994, 81-130nn. 
między jakościowym uposażeniem przedmiotów (w szczególności ludzi) a wartościami. To „ukazywanie” nie dokonuje się explicite, lecz raczej kryje się za sensami, wyznaczonymi przez wyrażenia językowe dzieła, w szczególności - za światem przedstawionym, choć może lepiej byłoby powiedzieć: $\mathrm{w}$ sensach i w świecie przedstawionym. Owo „ukazywanie” nie dotyczy jednostkowego faktu, lecz ejdosu. Poprzez fakt ukazywany jest ejdos, z którym perceptor nie tyle może się zapoznać, co może z nim obcować, oczywiście jeśli literackie dzieło sztuki jest udatne ${ }^{31}$.

Jak stwierdza Katarzyna Rosner, dzieło literackie jest „specyficznym rodzajem komunikatu, przynoszącym pewne treści poznawcze" czy „pewnym przekazem informacji i postaw ideologicznych, dotyczących świata istniejącego poza nim" ${ }^{2}$, a zatem - posiada roszczenie do prawdy w sensie klasycznym. Zaś jeden $z$ wybitnych polskich pisarzy współczesnych, Włodzimierz Odojewski, wprost domagał się, by literatura, przynajmniej ta poważna, mówiła „prawdę o świecie, o ludziach i o historii"33. Choć - by odwołać się do literatury proza realistyczna dla problematyki prawdy w dziele literackim może uchodzić za przykład szczególnie przejrzysty, dostrzeżone zasady, dotyczące prawdy w literaturze, można odnieść do całości literatury pięknej, bo tak jak różnorodna jest rzeczywistość, tak i różnorodna jest prawda o niej, także i ta literacka, a pozostając prawdą, może przybierać różne oblicza.

31 Na czym to obcowanie miałoby polegać, może przybliżyć fenomenologiczna koncepcja naoczności i opisu fenomenologicznego, który nie tyle ma informować o danych naocznych, co stawić odbiorcę tego opisu w ich obliczu. Na ten temat zob. np. J. Krokos, Fenomen i język, Studia Philosophiae Christianae 31(1995)1, 195-199; Tenże, Metody fenomenologiczne i ich aktualność. Zarys problemu, Studia Philosophiae Christianae 34(1998)2, 103-111.

32 K. Rosner, O funkcji poznawczej dzieła literackiego, Wrocław 1970, 7 i 9.

33 W. Odojewski, Raptularz krytyczny. Twórcy - dzieła - konteksty, red. S. Barć, Lublin 1994, 59. Zob. W. Tomaszewska, Wielowarstwowość prawdy literackiej w prozie Włodzimierza Odojewskiego, Roczniki Humanistyczne 57(2009)1, 59-72. 
Choć sformułowanie to ma charakter metaforyczny, wydaje się ono naprowadzać na prawdę w dziele literackim, która nie tyle coś mówi nam o transcendentnej rzeczywistości, lecz się w dziele literackim ukazuje jako integralna we współoddziaływaniu prawdy transcendentnej o rzeczywistości pozaliterackiej i własnej immanentnej prawdy świata przedstawionego. Dla dzieła sztuki literackiej prawda transcendentna jest materiałem, $\mathrm{z}$ której pisarz buduje prawdę immanentną dzieła, by poprzez nią czy w niej dać jego zdaniem prawdziwe rozumienie świata rzeczywistego. A jest to możliwe, jeśli immanentna prawda dzieła zostanie tak uwiarygodniona, że dzieło literackie, będąc przedmiotem czysto intencjonalnym, zostanie przez czytelnika przyjęte jako głos realnej osoby-pisarza o rzeczywistości. Prawda transcendentna, z której utkana jest prawda immanentna dzieła, tej prawdzie służy i w niej się roztapia tak, by prawda immanentna została rozpoznana jako przedłożone przez pisarza prawdziwe rozumienie świata transcendentnego. Prawda dzieła literackiego jest raczej prawdą rozumienia świata $\mathrm{w}$ jego różnorodności, niż prawdą wiedzy o nim; prawdą, która jest propozycją do zweryfikowania w bezpośrednim obcowaniu ze światem przedstawionym.

Gdy Władysław Stróżewski stwierdzał, że „Prawda jest warunkiem sine qua non sztuki”, że jest ona ,jednym ze sposobów ujawniania prawdy”, „nie wprost, lecz poprzez szczególne warunki, jakie dla jej objawienia się stwarza" 34 , odwołał się do następującej wypowiedzi Martina Heideggera: „W dziele zachodzi wydarzenie prawdy, mianowicie na sposób dzieła. Zgodnie $\mathrm{z}$ tym $\mathrm{z}$ góry określono istotę sztuki jako zatrzymywanie prawdy w dziele. A przecież określenie to jest celowo dwuznaczne. Mówi ono po pierwsze: sztuka jest ujmowaniem w (konkretnej - przyp. tłum.) postaci zadomawiającej się prawdy. Następuje to w tworzeniu jako wy-noszeniu (Hervor-bringen) nieskrytości bytu. Zatrzymywanie prawdy w dziele znaczy zarazem: uruchamianie i zapoczątkowywanie bycia dziełem. To

34 W. Stróżewski, Literatura i filozofia, Ruch Literacki 34(1995)6, 696. 
zachodzi w postaci zachowywania. Zatem sztuka jest stawaniem i wydarzaniem się prawdy. (...) Prawda jako prześwit i skrywanie bytu wydarza się poprzez poetyzowanie. Wszelka sztuka jest w istocie poezją, jako przyzwolenie na przybycie prawdy bytu jako takiego. Istotą sztuki, w której mieszczą się zarazem dzieło sztuki i artysta, jest zatrzymywanie prawdy w dziele" 35 .

Czy zatem w literackim dziele sztuki nie należałoby się doszukiwać raczej objawiania prawdy o złożonej i różnorodnej rzeczywistości, a nie jej mówienia? - pozostaje sprawą otwartą.

\section{BIBLIOGRAFIA}

Gierulanka D., Filozofia Romana Ingardena. Próba wniknięcia w strukturę catości dzieta, w: Fenomenologia Romana Ingardena, (Wydanie specjalne Studiów Filozoficznych), red. J. Kuczyński i in., IFiS PAN, Warszawa 1972, 70-90.

Heidegger M., O zródle dzieta sztuki, tłum. z niem. L. Falkiewicz, Sztuka i Filozofia (1992)5, 9-67.

Ingarden R., Odziele literackim. Badania zpogranicza ontologii, teorii jezyka ifilozofi literatury, tłum. z niem. M. Turowicz, Państwowe Wydawnictwo Naukowe, Warszawa $1988^{2}$.

Ingarden R., O poznawaniu dzieła literackiego, tłum. z niem. D. Gierulanka, Państwowe Wydawnictwo Naukowe, Warszawa 1976.

Ingarden R., Spór o istnienie świata, t. 1-3, Państwowe Wydawnictwo Naukowe, Warszawa $1987^{3}$.

Ingarden R., Studia zestetyki, t. 1-3, Państwowe Wydawnictwo Naukowe, Warszawa 1966- 1970.

Krokos J., Fenomen i jezyk, Studia Philosophiae Christianae 31(1995)1, 195-199.

Krokos J., Metody fenomenologiczne i ich aktualność. Zarys problemu, Studia Philosophiae Christianae 34(1998)2, 103-111.

Krokos J., O poznawaniu przedmiotów czysto intencjonalnych, Kwartalnik Filozoficzny 34(2008)2, 15-23.

Krokos J., Trójwymiar intencjonalności, Studia Philosophiae Christianae 52(2016)3, 51-67.

35 M. Heidegger, O źródle dzieła sztuki, tłum. z niem. L. Falkiewicz, Sztuka i Filozofia (1992)5, 53. 
Odojewski W., Raptularz krytyczny. Twórcy - dzieta - konteksty, red. S. Barć, Wydawnictwo Uniwersytetu Marii Curie-Skłodowskiej. Lublin 1994.

Prawda w literaturze, red. A. Tyszczyk, J. Borowski, I. Piekarski, Towarzystwo Naukowe KUL, Lublin 2009.

Rosner K., O funkcji poznawczej dzieta literackiego, Zakład Narodowy im. Ossolińskich, Wrocław 1970.

Stróżewski W., Jakości metafizyczne, w: Stownik pojęć flozoficznych Romana Ingardena, red. A.J. Nowak, L. Sosnowski, Universitas, Kraków 2001, 130-131. Stróżewski W., Literatura i filozofia, Ruch Literacki 34(1995)6, 693-708.

Tomaszewska W., Jakości metafizyczne w dziele literackim, Kwartalnik Filozoficzny 36(2008)2, 123-131.

Tomaszewska W., Jakości metafizyczne w dziele sztuki literackiej i ich poznawanie, Studia Philosophiae Christianae 50(2014)2, 125-144.

Tomaszewska W., Wielowarstwowośc prawdy literackiej w prozie Wtodzimierza Odojerwskiego, Roczniki Humanistyczne 57(2009)1, 59-72.

Tyszczyk A., Estetyczne i metafizyczne aspekty aksjologii literackiej Romana Ingardena, RW KUL, Lublin 1993.

Ulicka D., Granice literatury i pogranicza literaturoznawstwa. Fenomenologia Romana Ingardena w świetle filozofii lingwistycznej, Wydawnictwo Wydziału Polonistyki Uniwersytetu Warszawskiego, Warszawa 1999.

Ziomek J., Prace ostatnie. Literatura i nauka o literaturze, Wydawnictwo Naukowe PWN, Warszawa 1994.

\title{
SOME REMARKS ON TRUTH IN LITERATURE
}

\begin{abstract}
This article deals with the issue of truth in literature by considering Roman Ingarden's account. He denies that literary work as a work of art can be true in a logical sense. As a purely intentional object, a literary work of art decides nothing about a transcendent world. The truth in a literary work, however, can be understood as its revelation.
\end{abstract}

Keywords: truth; literary work; Roman Ingarden

Wiesława Tomaszewska

Uniwersytet Kardynała Stefana Wyszyńskiego w Warszawie, Instytut Literaturoznawstwa (Cardinal Stefan Wyszyński University in Warsaw, Institute of Literature, Poland)

ORCID: https://orcid.org/0000-0002-2766-7943

w.tomaszewska@uksw.edu.pl

DOI: 10.21697/spch.2020.56.4.16 